\title{
Language Specifics of Writing a Paper in English ${ }^{1}$
}

\author{
Jana Vančíková ${ }^{2}$
}

\section{Abstract}

The paper aims to define the specifics of academic writing with focus on English language. It presents the linguistic features of academic text in comparison to the nonacademic writing. Secondly, it provides the extended list of typical expressions used in different parts of academic paper. The paper gives many linguistic examples of expressions frequently used in the research and scientific papers.

\section{Key words}

Academic writing, scientific English.

JEL Classification: A23, A29, I23

\section{Introduction}

The role of communication in the research has been intensified. There is an increasing pressure on researchers to publish not only in the national publications but to shift the focus on international ones. Writing and publishing became a significant part of researchers and PhD students' assessment. This should be also reflected in the education and training of PhD students and young researchers, which would contribute to higher quality of research system and outputs. This is also an objective of the research project KEGA no. 3/7284/09 named The principles and methods of research work for students and academics at business schools and universities (Zásady a metódy vedeckej práce vzdelávacích a kvalifikačných stupňov vysokej školy obchodno-vedného zamerania).

Academic writing is a skill that needs to be trained, developed, and deepened. Moreover, in the global and international research environment, the students and researchers' training should be also oriented on specific linguistic features of academic text in English. The aim of the paper is to provide handout on scientific English language focusing on specifics of scientific writing style, as well as to give useful sample phrases that may be used in different parts of academic text.

\section{Some aspects of the academic writing}

The expansion of the PhD studies requires the extended and deepened education at the universities in order to facilitate the training of PhD students. Students are sup-

1 The paper is published as a part of the research project KEGA Zásady a metódy vedeckej práce vzdelávacích a kvalifikačných stupňov vysokej školy obchodno-vedného zamerania MŠ SR č. 3/7284/09/OF EU, 2009-2011.

2 Ing. Jana Vančíková, PhD.; University of Economics in Bratislava, Faculty of Commerce, Department of services and tourism, Dolnozemska cesta 1, 85235 Bratislava; E-mail: jana.vancikova@gmail.sk 
posed to learn different professional skills, as well as attitudes and principles of the research and science. Michalová (2009) points out the rules and suggestions of correct research practice, such as the organization, management, research education, training, and publishing. The author further defines the skills for communicating the results of the research where, among others, belong:

- the ability to use simple written language,

- the ability to use suitable writing style,

- to attract the readers,

- to promote the science,

- $\quad$ to be able to use tools and suitable writing style for knowledge distribution.

Recently, the researchers turned to talk about "research communication" rather than "the language of science". This is, indeed, a great shift from the point that language has become a part of knowledge distribution process and way of contributing to scientific solidarity (Čmejrková et al., 1999).

Also in the process of assessment the relevant part of the students' output is communication of the research results, whereas the most common way is writing. PhD students have to gain certain amount of credits in order to be accepted for theses defence. The credits include not only studying and passing exams from the relevant subject but also participating in a research teams and writing papers on the topic of student's interest.

The papers are expected to have high level of quality, as for the content, as well as for the style of writing, formal and visual aspects. Further, the papers are usually peer-reviewed, which excludes the publication of the papers of low quality and writing without profound preparation.

Writing is a part of communication process of the students. Holubcová \& Bažó (2010) identifies different lags and problems in research communication. Young researchers often fail to communicate their research results clearly, transparently and effectively not only to their colleagues, students but especially to the professional or laic readers. There are different ways on how to make the research and scientific results popular. The classification of the communication can be found e.g. in Bednárik et al. (2008) and IVPaR (2008)

These days the credit system is under the consolidation in order to reach the aim of universities to enhance the research work and papers towards international publications and research activities. Current trends toward improving the quality of the research output rather than the quantity open up the space for new areas of education focused on PhD students. The attention should be given on learning the research principles, rules and ethics but also training the analytical and critical writing should be put to focus. 


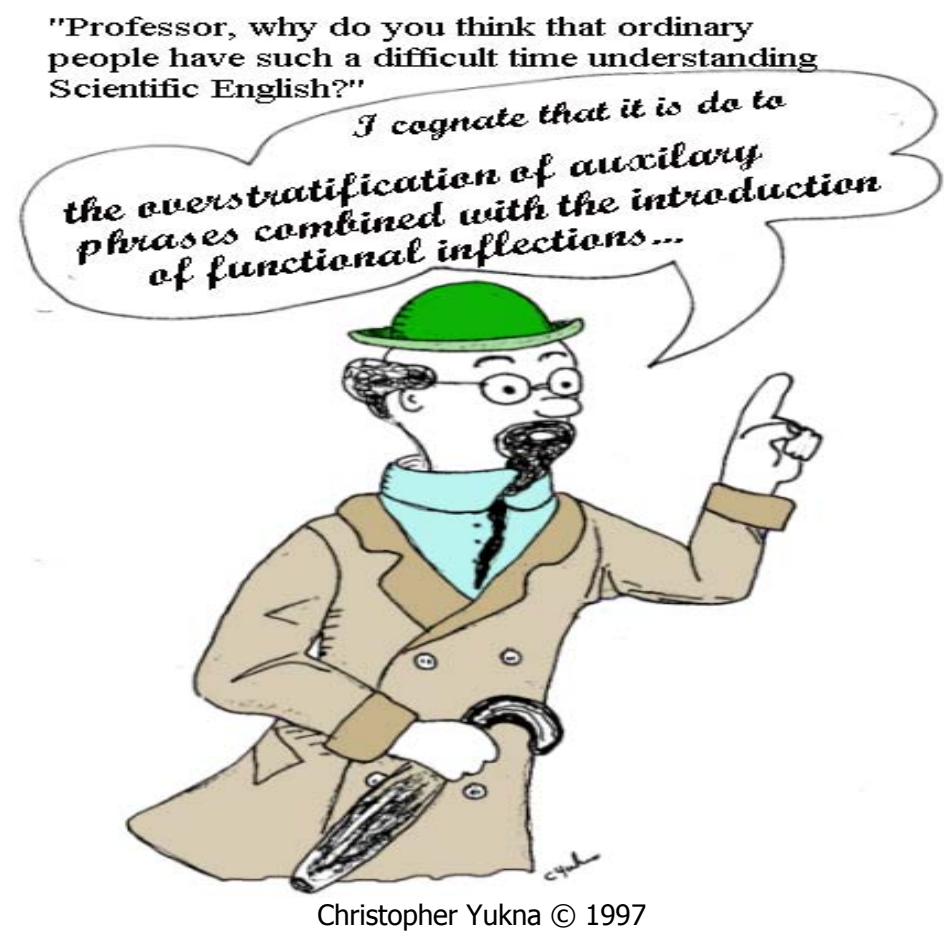

In the process of internationalisation, globalisation, and because of the pressure the requirements to publish in English, we found it very important to train skills of analytical writing in English. In English language, it is possible to identify many linguistic features representing the professional paper that are distinct from regular - generically used language.

Some phrases may seem so flowery that even professionals - scientists themselves make fun of the specific writing style typically used in research papers. Some of the scientific phrases and their explanation were originally created by author Graham (1957) and may have been modified by years of using. These are listed in the table 1 and are comically explained what scientists actually mean when they write certain phrases.

Table 1 What scientist mean when they use certain academic writing

\begin{tabular}{|ll|}
\hline WHEN SCIENTISTS WRITE: & THEY REALLY MEAN: \\
\hline It has long been known that. . . . & $\begin{array}{l}\text { I haven't bothered to look up the } \\
\text { original reference }\end{array}$ \\
\hline $\begin{array}{l}\ldots \text { of great theoretical and practical impor- } \\
\text { tance }\end{array}$ & $\ldots$ interesting to me \\
\hline $\begin{array}{l}\text { While it has not been possible to provide defi- } \\
\text { nite answers to these questions ... }\end{array}$ & $\begin{array}{l}\text { The experiments didn't work out, but } \\
\text { I figured I could at least get a publi- } \\
\text { cation out of it }\end{array}$ \\
\hline
\end{tabular}




\begin{tabular}{|c|c|}
\hline $\begin{array}{l}\text { The W-Pb system was chosen as especially } \\
\text { suitable to show the predicted behaviour. . . }\end{array}$ & $\begin{array}{l}\text { The fellow in the next lab had some } \\
\text { already made up }\end{array}$ \\
\hline $\begin{array}{l}\text { High-purity .... } \\
\text { Very high purity .... } \\
\text { Extremely high purity ... } \\
\text { Super-purity ... } \\
\text { Spectroscopically pure ... }\end{array}$ & $\begin{array}{l}\text { Composition unknown except for the } \\
\text { exaggerated claims of the supplier }\end{array}$ \\
\hline A fiducial reference line ... & A scratch \\
\hline $\begin{array}{l}\text { Three of the samples were chosen for detailed } \\
\text { study . . }\end{array}$ & $\begin{array}{l}\text { The results on the others didn't make } \\
\text { sense and were ignored }\end{array}$ \\
\hline$\ldots$ accidentally strained during mounting & $\ldots$ dropped on the floor \\
\hline $\begin{array}{l}\text {... handled with extreme care throughout the } \\
\text { experiments }\end{array}$ & $\ldots$ not dropped on the floor \\
\hline Typical results are shown ... . & The best results are shown \\
\hline $\begin{array}{l}\text { Although some detail has been lost in repro- } \\
\text { duction, it is clear from the original micrograph } \\
\text { that ... }\end{array}$ & $\begin{array}{l}\text { It is impossible to tell from the mi- } \\
\text { crograph }\end{array}$ \\
\hline Presumably at longer times ... & I didn't take time to find out \\
\hline $\begin{array}{l}\text { The agreement with the predicted curve is ex- } \\
\text { cellent }\end{array}$ & fair \\
\hline good & poor \\
\hline satisfactory & doubtful \\
\hline fair & imaginary \\
\hline .. as good as could be expected & non-existent \\
\hline These results will be reported at a later date & $\begin{array}{l}\text { I might possibly get around to this } \\
\text { sometime }\end{array}$ \\
\hline The most reliable values are those of Jones & He was a student of mine \\
\hline $\begin{array}{l}\text { It is suggested that ... } \\
\text { It is believed that ... } \\
\text { It may be that ... }\end{array}$ & I think \\
\hline It is generally believed that ... & A couple of other guys think so too \\
\hline It might be argued that ... & $\begin{array}{l}\text { I have such a good answer to this } \\
\text { objection that I shall now raise it }\end{array}$ \\
\hline
\end{tabular}


It is clear that much additional work will be re- I don't understand it
quired before a complete understanding . . .

Unfortunately, a quantitative theory to account Neither does anybody else for these effects has not been formulated

Correct within an order of magnitude Wrong

It is to be hoped that this work will stimulate further work in the field

This paper isn't very good, but neither are any of the others in this miserable subject

Thanks are due to Joe Glotz for assistance with Glotz did the work and Doe explained the experiments and to John Doe for valuable what it meant discussions

Source: Graham, 1957.

\section{$2 \quad$ Language specifics of scientific English}

In the table above we could have proved that there are real differences in the scientific and normal English language. In the following part of the paper we attempt to comprehensively identify, explain and address the most significant linguistic rules that we find to be important to know in order to create a good English academic text. These rules may be limited regarding the complexity of linguistic topics, however, we do concentrate on those that influence the overall quality and transparency of the academic writing.

It is important to consider that each scientific discipline have the specific terminology as well as stylistic rules of research writing. The aim in this paper is not to cover all areas of professions rather than concentrate on generally applicable rules with some specifics relevant to business field of study.

\subsection{Hedging - the oratorical cautious}

As we mentioned above, each discipline has its specifics that are reflected in the published results not only in the content but also in the style of writing. However, we can identify some common points that are important to be considered when writing the academic text in any discipline (Saber, 2008):

- historical

- replicable

- empirical

- probabilistic

- tentative.

In particular example, these aspects can be seen in a phrase that indicates the limits of one's study: 
Our study may have had inadequate statistical power to detect such interactions. In general, such change in writing style can be called "hedging", which may mean something like a "verbal diplomacy". Very frequent mean of hedging in the academic text is using a modal verb "may". It is more correct and ethical to write

This may have an economic importance.

rather than

This has an economic importance.

Other examples of the correct use of "may" in order to apply hedging in the text are:

- Our data may also provide...

- Our findings may not be generalizable to customers who...

- The absolute event rates reported may not be valid for a contemporary group of...

The way how the part of a text or a phrase begins may also make the research arguments more relative:

- One potential explanation is that...

- Although we do not have data on...

- Despite the lack of evidence...

- It remains a possibility that collected date may have been influenced by...

\subsection{IMRAD structure}

Research paper is usually divided into particular parts that are clearly outlined. Very frequent structure used in many disciplines is called IMRAD: introduction, methods, results and discussion.

\section{Introduction}

While creating the introducing part of the paper, we can apply so called "CARS" Model (Figure 1) that were introduced by John Swales and Christine Feak (2000) and is considered by more authors and lecturers as very useful tool for academic writers in general. It can be observed in many research articles.

Figure 1 "CARS" Model

Move 1 - Establish a research territory

Move 2 - Establish a niche

Move 3 - Occupy the niche

Source: Academic Persona: Creating a Research Space (the Cars Model). 
The CARS model outlines three steps for creating a research space that is related to the concept of niche. In many cases, writers are taught to move from a general to specific focus in their writing. However, conceptualizing the writing in this manner could be too simplistic - it seems to imply a single step from a general description to a specific description without really specifying how or why that move should be made or what the real purpose behind making such a move is. This is where the CARS model becomes really valuable. It consists of three main steps and a series of sub-steps that more clearly define what the individual steps are that the writer needs to take:

- Move 1: Establishing a research territory

- step 1: claiming centrality, and/or

- step 2: placing your research within the field respectively making topic generalization, and/or

- step 3: reviewing items of previous research

- Move 2: Establishing a niche

- step 1a: Counter-claiming, or

- step 1b: Indicating a gap in current research, or

- step 1c: Question raising, or

- step 1d: Continuing a tradition

- Move 3: Occupying the niche

- step 1a: Outlining purposes, or

- step 1b: Announcing present research

- step 2: Announcing principle findings

- step 3: Indicating research article structure

This suggests that introduction serves for establishing a niche within particular subject and current state of knowledge, e.g. it provides the references to previous studies and papers. This fact is also reflected in the tense used in phrases. Very common tense that may occur is present perfect. Some phrases typical for introduction part of the paper may be the following:

In a recent paper...

It has been suggested that...

...has been shown to be...

...have been found to be...

... one of the most extensively studied of these...

.... were initially thought to...

... is a rapidly developing field of research...

Some typical phrases may be used in order to indicate the present state of knowledge on the topic covered in the paper:

Recently, there has been a spate of interest in how to...

In recent years researchers have become increasingly interested in...

The possibility that... has generated interest in...

The explication of the relationship between ....and... is a classic problem of...

The study of... has become an important aspect of...

The theory that... has led to the hope that...

Many investigators have recently turned to...

A central issue in... is the validity of...

The well-known... phenomena have been favourite topics for analysis in... 
The introduction is a part of the text where we present the topic and at the same time we may indicate the structure, content, and plan of the paper:

Here we report...

In the current study, we investigated...

For this paper we further characterized...

This paper includes a discussion of...

Results of work from our lab have revealed that...

Findings from... have indicated that...

\section{Methods, discussion and results}

For these sections of the paper we can point out some typical expressions and verbs well suited for this experimental and analytical part of the text. It is important to note that typical form of used verbs is a passive form, as was/were used...was/were recorded... and so on. We can also notice the frequent use of recurrent verbs in the text, such as: report, calibrate, perform, measure, obtain, collect, etc.

Tense applied in the section that describes and analyses the results of the research is mostly present simple. It can be indicated in different instances. For example, in the sections that includes graphical tools as figures, tables, graphs and curves may have the following syntagm:

Reveal... as shown in Figures 1 and 2...

Data are given in Table 1

As can be seen from these figures...

Here, it may be noteworthy to set the vocabulary for description of curves. The starting point of the curve is called "origin", the horizontal axis is "abscissa axis" and the vertical axis is "ordinate axis". The shape of the curve is called "the slope".

The curves, as well as other graphic tools are connected with certain typical verbs used in order to describe them. These are:

Figure 1 shows / displays / indicates / represents / illustrates / depicts / compares / demonstrates...

As shown in Figure 1...

Noticing the style of writing in the section that deals with the research results, we can indicate the following typical expressions:

... was found to be...

Findings for... show that.../represent a $10 \%$ increase/decrease in...

It is noteworthy that...

We were surprised to find that...

One striking finding of the current study is that...

To have a significant effect/impact on...

When we want to include to the text a comparison, a description of differences or others, we may also concentrate on using convenient expressions, as follows:

Is similar to... Is different from...

To differ (from)

To alter 
While results from previous studies have found that..., we....

No changes were found in...

The "results" section may be often connected with "discussion". That is why the use of the following verbs and phrases is difficult to typically classify for particular section. It is important to note the intention of used phrase. For example, in order to assess the results and findings of the paper, the following expressions may come up:

We investigated...

Our results support the notion that...

Our results indicate that...

If the author prefers using more neutral style of writing, he/she should consider applying different kind of phrases, such as:

One significant difference is...

We suggest that...

The consistent appearance of this motif...

If the author means to outline the possible areas of further development of research study, we suggest an example of suitable phrase:

Additional studies are necessary to understand...

\section{Conclusion}

When creating the text for the conclusions, it is important to take into consideration four parts of the conclusion that most often includes:

- $\quad$ summary of main results

- brief synthesis of the strong and weak aspects of the study

- recommendations

- $\quad$ perspective for the future research

\subsection{Irregular plural}

In the academic writing and scientific language, in general, we often find the terminology - nouns - that have irregular plural. Further, we provide the table that summarizes the most frequent irregular plurals.

Table 2 Examples of irregular plurals

\begin{tabular}{|l|l|}
\hline Singular & Plural \\
\hline Analysis & Analyses \\
\hline Appendix & Appendices \\
\hline Axis & Axes \\
\hline Criterion & Criteria \\
\hline Formula & Formula \\
\hline Hypothesis & Hypotheses \\
\hline Matrix & Matrices \\
\hline Maximum & Maxima \\
\hline
\end{tabular}




\begin{tabular}{|l|l|}
\hline Medium & Media \\
\hline Minimum & Minima \\
\hline Momentum & Momenta \\
\hline Nucleus & Nuclei \\
\hline Parenthesis & Parentheses \\
\hline Phenomenon & Phenomena \\
\hline Quantum & Quanta \\
\hline Radius & Radii \\
\hline Spectrum & Spectra \\
\hline Thesis & Theses \\
\hline
\end{tabular}

Source: Saber, 2008.

\subsection{Transition words and academic register in English language}

With the aim to improve academic writing, it is required to make sure that the ideas, both in sentences and paragraphs, stick together or have coherence and that the gap between ideas is bridged smoothly. One way to do this is by using transition words (or transitional words), phrases or techniques that help bring two ideas together. Transitional words and phrases represent one way of gaining coherence. Certain words help continue an idea, indicate a shift of thought or contrast, or sum up a conclusion. Here, we indicate the list of words that may be used to pull sentences and paragraphs together:

\section{For continuing a common line of reasoning (discourse markers)...}

One of the most important aspects of writing good academic English is the ability to ling clauses, sentences and paragraphs to each other by means of so-called "discourse markers". There exists a wide variety of words and phrases with precisely this function, a few of which are assembled bellow:

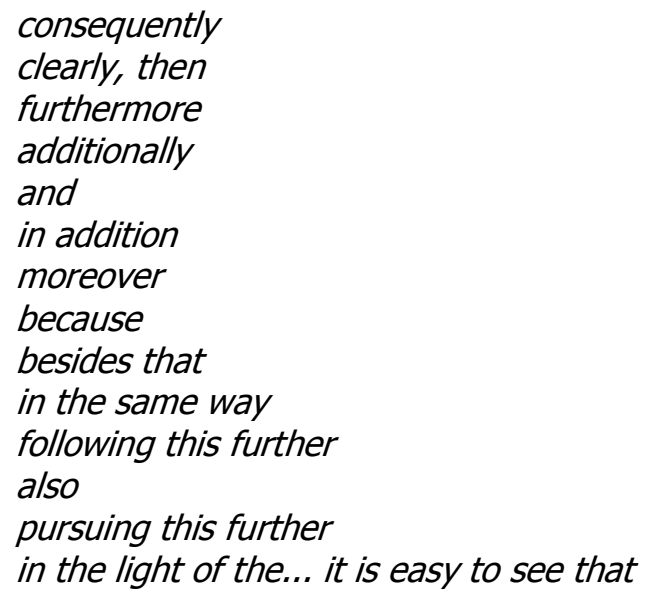




\title{
To make a comparison and contrast...
}

One of the most obvious things which a researcher must be prepared to do is to compare and contrast two or more different things. There are a number of ways the researcher might go about this. One possibility would be to say all that he/she want to say about item $X$, and then to turn to item $Y$, comparing and contrasting point by point. Another possible way would be for the researcher to present one aspect of $X$, and then present the corresponding aspect of $Y$, and so on until all the aspects are covered. Here are some words and phrases which are associated with comparison:

\author{
likewise \\ similarly \\ at the same time \\ once more; once again \\ in like manner \\ in much the same way \\ compared to $X$
}

If the aim of the text is to change the line of reasoning and indicate a contrast in the statements, here are few typical expressions applicable to this:

conversely
however
even so
on the other hand
but
yet
nevertheless
on the contrary
unlike $Y$
nonetheless
in spite of this/that
in contrast
although
even though
instead

\section{For opening, general use and concession rather than qualification...}

In the academic papers the paragraphs, sections and phrases are initially opened with expressions that supports the logical line with previous text. The expressions bellow does not necessary need to be used in order to open part of the text but also for general use. In this case it may often happen due to the fact that any mature researcher is wary of making generalisations. Very often when one makes statements, we tend to like to qualify them, so that they appear more fair, balanced, and judicious. The following are some words and phrases by which qualification can be expressed:
admittedly
assuredly
certainly
granted
no doubt 


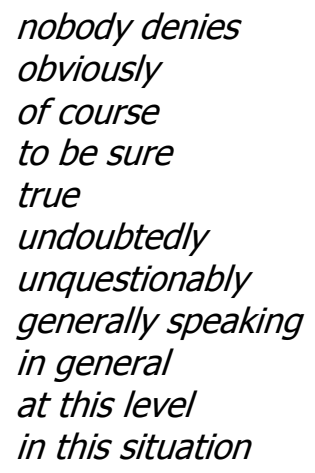

Here follows the expression indicating the example often generally used in academic papers:

for example
similarly
in order to $y$
usually
for instance
in particular
that is
especially
frequently
in general
generally
e.g.
specifically
occasionally

For the final points of a paragraph or a paper, we may use expression such as:

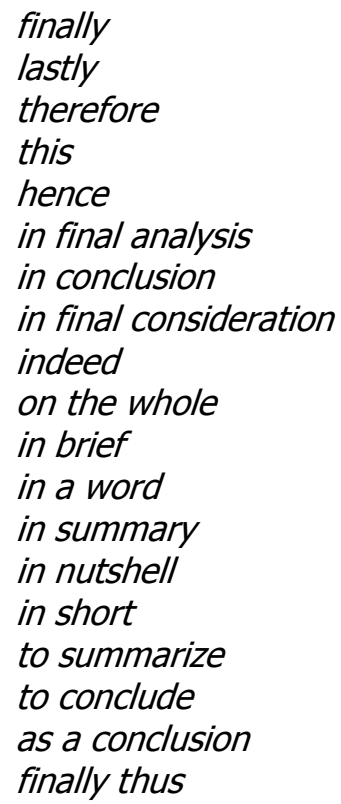




\section{To describe the cause, effect or the consequence...}

Any serious analysis of events or processes will involve a discussion of causes and effects. It is important to remember that very often a case may have more than one effect, while an effect may have more than one cause. When something causes something else, which in turn results in a third thing happening, we call this a "chain reaction". Every researcher needs to be cautious about ever-present temptation to regard two phenomena which are clearly related to each other in time as being causally related. Here are some expressions that indicate causes, effects and consequences:

therefore
consequently
finally
thus
as a result
as a consequence
for this reason
due to Y
since
because
and so
accordingly
so
and that is why

However, a danger may occur when confusing "cause", "effect" and "consequence". Causes are very difficult to identify with absolute certainty, and if an author is not absolutely sure then it is important to be honest and reflect it also in academic paper. Here we provide some phrases which express the tentative, the provision, the speculative:

It would seem/appear that...

It is quite possible that...

It is likely that...

It is said that...

Presumably...

There is evidence to suggest that...

$X$ may be responsible for $Y$.

Recent findings suggest that...

There is a tendency for $X$ to ( + infinitive)

There appears to be a (statistical) correlation between $X$ and $Y$.

Transitional chains to use in separating sections of a paragraph which is arranged chronologically:

first... second... third...

generally... furthermore... finally

in the first place... also... lastly

in the first place... pursuing this further... finally

to be sure... additionally... lastly

in the first place... just in the same way... finally

basically... similarly... as well 
To restate a point within a paragraph in another way or in a more exacting way: in other words point in fact specifically

To express the sequence or time we may use:

after
afterwards
as soon as
at first
at last
before
before long
finally
first... second... third
in the first place
in the meantime
later
meanwhile
next
soon
then

To develop or to extend the idea:
besides
as noted earlier
moreover
again
for that matter
to be sure
in other words
in fact
in addition
surely
on the whole
furthermore
besides that
of course
as a matter of fact
to repeat
then, too
naturally
indeed

Before embarking on any piece of writing, the author must be very sure of whom his/her targeted readers are. Thus, if he/she aims to attract the widest possible readership, the tone and the style of language he/she uses will be quite different from those employed by the author of a learned dissertation destined for a highly specialised readership. 
Then again, the learned dissertation will be very different in language from a paper read out at an academic conference, from a lecture given to students, or from a radio-talk delivered to the general public. The facts is that great differences of register exist, and nowhere more so than between spoken English and written English, and different rules apply. The most important thing is simply to be consistent in the language that is used in the paper.

There are no real short-cuts to mastering register. The best way is long exposure to the language, especially reading of academic text, and above all practice in writing the language. Another way how to be prepared for writing an academic paper in English is to prepare own list of scientific phrases and expressions that may be easily used when needed.

\section{Conclusion}

Doing and academic piece of writing in English is a complex work. Written academic English contains many specifics, they can be, however, summarized in a practical list of expressions. Academic paper, on one hand, needs to reflect the aim to popularize the science and make it easy-to-reach by general public. On the other hand, the style of writing (or the register) has to be exact, logical, consistent, and should transparently reflect the content and targeted readers. That means the authors are required to be cautious from oratorical point of view, and at the same time to be exact in statements and to fulfil the space meant for introductory, core and summarizing parts of the text. In every section or paragraph of academic paper, a logical sequence, reasoning and transparent causality needs to applied and proved. This all influences the quality of final academic paper. To ensure the comprehensiveness of the academic text, the researchers are encouraged to use transition words, hedging and pay attention on use of latin-origin words that are very likely to be used in scholarly writings. Language specifics in scientific English are quite many, however, by creating own list of academic expressions, the process of writing an English paper may be more efficient. Nevertheless, mastering the academic writing style is a long time process that requires time spent with reading English texts and training from the beginning of research career.

\section{References}

Academic Persona. Creating a Research Space (the CARS Model). Retrieved June 3, 2010, from http://apresource.wordpress.com/2007/05/08/the-cars-modelcreating-a-research-space/

Bednárik, R., Holubová, B. \& Repková, K. et al. (2008). Tréning komunikácie vedy. Bratislava : Inštitút pre výskum práce a rodiny.

Čmejrková, S., Daneš, F. \& Světlá, J. (1999). Jak napsat odborný text. Praha : Leda.

Dmitrijeva, E. A. (2004). Hints to master essay writing. Minsk : Bieloruská hospodárska univerzita. Retrieved June 6, 2010, from

http://webcache.googleusercontent.com/search?q=cache:C_MBjd173zs]:www.fir. 
bsu.by/chairs/essh/publications_essh/Hints_to_Master_Essay_Writing_2004.doc+ $\% 22$ one+of +the+most+obvious+things + which+any+writer+must+be $\% 22 \& c d=$ $1 \& \mathrm{hl}=\mathrm{sk} \& \mathrm{ct}=\mathrm{clnk} \& \mathrm{gl}=\mathrm{sk}$

Graham, C. B. (1957). Metal Progress 71, volume 75. Retrieved May 29, 2010, from http://www.astro.rug.nl/ terlouw/glossary.html

Holubcová, I. \& Bažó, L. (2010). K otázkam komunikácie na vysokej škole obchodnovedného zamerania. Studia commercialia Bratislavensia, 3(10). 209-225.

IVPaR. (2008). Vedecká komunikácia a komunikácia vedy. Bratislava : Inštitút pre výskum práce a rodiny.

Kot, J. (2004). Lecture notes distributed at course of English for translators at SJS. Palisady, Bratislava.

LARA: Transition words. Retrieved June 3, 2010, from http://larae.net/write/transition.html

Michalová, V. (2008). K aktuálnym otázkam zásad a metód vedeckej práce vysokej školy obchodno-vedného zamerania. Studia Commercialia Bratislavensia, 2 (8). 110-123.

Saber, A. (2008). Lecture notes distributed at course of English for doctoral students. ENS Cachan, France.

Swales, J. M. \& Feak, Ch. B. (2000). English in Today's Research World. A writing guide. Michigan : University of Michigan Press.

Yukna, Ch. (1997). Writing Scientific English. Retrieved June 8, 2010, from http://www.emse.fr/ yukna/ENG/scienceE.htm 